Chitja Twala

Senior Lecturer,

Department of History,

University of the

Free State.

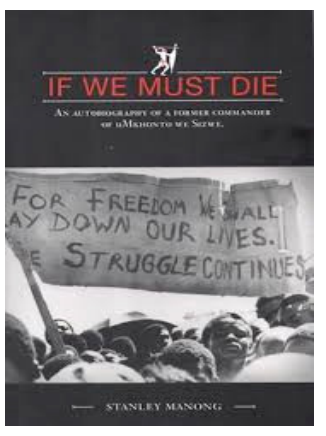

DOI: https://dx.doi. org/10.18820/24150509/ JCH42.v1.11

ISSN 0258-2422 (Print) ISSN 2415-0509 (Online)

Journal for Contemporary History 2017 42(1):177-181

(C) UV/UFS

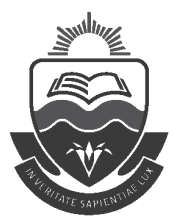

\section{BOOK REVIEW /}

BOEKBESPREKING

IF WE MUST DIE: AN

AUTOBIOGRAPHY OF A FORMER

COMMANDER OF UMKHONTO

WE SIZWE

Stanley Manong, If we must die: An autobiography of a former commander of uMkhonto we Sizwe. S.I.: Nkuleleko Publishers, 2015. ISBN 978-0-620-62946-1. 331 pages.

This publication posited, apart from infusing a new vibe into the historiography of the liberation struggle, that there was a serious crisis within the African National Congress (ANC) movement in terms of membership and leadership from the 1960s up to the period after the 2012 Mangaung Conference. This occasioned a further reconfiguration of certain discourses surrounding the pre- and postexile history of the ANC. As highlighted in this book, the major challenges of the movement were, to some extent, worsened by the organisational and survival tendencies of the ANC in exile. The exile history of the ANC, Manong argues, had an impact on the governance of the movement in post-apartheid South Africa.

The book is divided into 21 chapters which, in one way or another, serve to educate, as well as to caution historians and scholars of the liberation struggle - in particular the history of the ANC - to take into consideration the life stories of those political activists who took part in the struggle for liberation in South Africa. Therefore, this publication constitutes a personal account of Manong's recollection of the history of the ANC. The book assists in understanding that, in each polity and/or region, as there are different historical epochs, so are the perceptions and recollections of the struggle for liberation. A closer analysis of the book, especially with regard to how pertinent historical questions and discourses were framed, offers invaluable insights into the struggle history of the ANC. This is evident in the explication of the different perspectives on how liberation-related phenomena 
became inextricably related to the discourses of power and ideology in historical time and space. The author has an extensive recollection of, and reference to the code or pseudo-names of many of the MK cadres used during the exile years. To name just a few examples: the author's pseudo-name was Bangazwe Nkululeko (meaning: Politics Freedom); Boy Adelphus Mvemve was John Dube; Mongameli Johnson Tshali was Lennox Lagu; Abie Molaba was Goodman Soweto; Paul Mashinini was Jackie Mabuza; Joel Netshitenzhe (Peter Ramokoa or Peter Mayibuye); Pule Moses Malebane was Elliot "Piper" Mazibuko; Patrick Diphoko was Simon Faku; Lebona Mosia was Zoyisile "Zet” Mati; Johnson Lubisi was Jimmy Dyantyi.

The introductory chapter provides the author's reasons for interrogating the liberation struggle of South Africa and why Umkhonto we Sizwe (MK) appealed to him as a valuable platform to pursue this. The author describes the book as a tribute, through the lens of his life, to all the members of the ANC and MK who dedicated their lives to the eradication of apartheid. Equally, the book analyses the causes of the mutinies, due to the abuses perpetuated against MK members by the ANC's Security Department, commonly known as imbokodo. The first chapter provides a back-and-forth narration of Manong's exile life, his studies in engineering abroad, and his return to South Africa after the unbanning of the ANC. Like many other political activists of the time, the author also narrates his experiences in the late 1970s with the likes of Ronald "Rocks" Mashinini, who had a significant influence on his political life. The second and the third chapters are about the killing of the Cradock Four, namely, Ghandi Gangathumlungu Hlekani, Jacques Jamani Goniwe, Ben Ngalo and Lennox Melani, and the commencement of the author's political activism as a high school student. Political activism remained part of his life when he went to Mmadikoti Technikon in Seshego to study civil engineering. During this period he denied recruitment as a spy or informer for the Bureau of State Security (BOSS) in exchange for a bursary to study at the Technikon. This is an indication as to how the student body was infiltrated by BOSS personnel. During this time, students from the Technikon used to spend the long weekends in Swaziland for political education under the pretext of excursions. On page 40, Manong recalls that it was in Swaziland where students met with Keith Mokoape of the ANC, who used to give them copies of Mayibuye and Sechaba to be distributed in South Africa.

Chapters four and five discuss the underground activities and the author's journey into exile respectively. The 1975 liberation struggles in Southern Africa by means of the liberation of Mozambique on 25 June and of Angola on 11 November, had an enormous influence on the author. The victory for UNITA and the MPLA respectively, weakened the apartheid government militarily, because the above two liberation movements had close ties with and were sympathetic to the ANC. In chapter five, Manong recalls his short stint in Mozambique and his initiation into the rank and file members of the ANC. 
Chapters six, seven and eight summarise the experiences of the ANC cadres in exile. Singing revolutionary songs and being inspired by OR Tambo's leadership in exile, became the order of the day to the young recruits of MK. The life situation and appalling conditions of the Benguela camp, which led to the dismay of the young recruits, are highlighted. On page 62, Manong states the following about the conditions, "The place did not resemble a facility that could produce fighters capable of overthrowing the apartheid regime". This, to a certain extent, demoralised the new recruits. It was in Benguela where they were introduced to military tactics. The Angolan Army, FAPLA, was used to train the ANC cadres. Later, the training camp moved to Novo Catengue, south of Benguela. It was in these camps that the news of the attempted coup of Agonstinho Neto's government by Nito Alves as Minister of International Administration made the ANC cadres nervous. Alves was said to have frustrated and sabotaged attempts by Neto to provide military assistance to the ANC, him being unsympathetic to the ANC's liberation course. Despite the above challenges and the failed coup, military training included courses on military topography, military engineering, military tactics, firearms, artillery, first aid and political education. Rumours in the camp of the ANC being captured by the Tswanas had some negative effects on the trainees. On page 80, Manong states, "In the camps, Rocks shared a room with John Mosia (Absolom Mampe) and Mduduzi Sydney Gwamanda (James Makhulu), who was the author of the letter addressed to the camp administration complaining about alleged Tswana tribalism [...] They said without exception all commanders and commissars that were appointed were Tswana speaking." This demon of intra-party ethnic capture of the ANC characterised the nature of the ANC in exile. In the other camps in Angola, for instance Funda and Quibaxe, aspects, such as the handling of small firearms, were incorporated into the sabotage and urban guerrilla warfare courses taught.

Chapter nine deals with the deployment of MK cadres and the reorganisation of the MK Botswana machinery after the withdrawal of Keith Mokoape and Snuki Zikalala from Botswana. The withdrawal of the two was due to the pressure exerted by the apartheid government on Botswana. They were replaced by Thabo Mavuyo and Stanley Manong. While in Botswana, Manong experienced the hostilities that existed between members of the ANC and those of the BCM, especially Lefifi Tladi who was critical of the ANC. In addition, some members of the Group of Eight, such as Tennyson Makiwane, who were expelled from the ANC in September 1975, were present in Botswana. Chapter ten carries the title of the book, If we must die. In this chapter, the author highlights the significance of the deployment of MK cadres in the country. The first phase of the operations involved the infiltration of units, consisting of three cadres to carry out reconnaissance. As early as 1978, AK-47s were sent into Botswana. 
In chapter eleven the author explains the training experiences in Zambia, which became known as the Communist Guerrilla Training (CGT). It was during this training that MK cadres trained with ZIPRA guerrilla fighters. Although the two groups had the same liberation course, the situations in Zimbabwe and South Africa were not the same. Chapter twelve and thirteen highlight the differences amongst the leadership of the ANC in terms of pursuing the liberation struggle with a militaristic approach which lacked strong political support from the masses of the people. The ANC showed signs of being infiltrated by some members who were on the pay-roll of the apartheid government. The operations of the ANC were leaked to the apartheid government by people, who later became known as the Askaris. Although the ANC tried to address this situation, the infiltration was excessive.

Chapters fourteen to seventeen deal with the less discussed and neglected history of the ANC, in so far as the mutinies in exile were concerned. The chapters address the situation in the camps and how those suspected of being informers/spies were dealt with by the ANC. In chapter fourteen the author laments that nothing has been documented on how imbokodo (ANC security) treated those who were detained in the Iran camp. There were differences between Manong and Andrew Masondo (National Commissar) on the issue of the treatment of MK cadres in Iran. MK cadres who had breached camp discipline were fastened to trees, beaten and made to spend the night in the same position in which they were fastened, to be released only the following day. In order to investigate the severity of the mutinies in the MK camps, the Stuart Commission was established. It was to investigate, amongst other, the root cause of the disturbances and the nature and the genuineness of the grievances.

Chapter eighteen discusses the political circumstances that led to the ANC's Kabwe Conference and the resolutions taken. The divisions within the leadership of the movement were also discussed. Although there were disagreements, the issue of mutinies was also discussed. In chapter nineteen, the author discusses the Stuart Commission's Report. One of the findings of the Commission was that the relationship between the rank and file and the camp administration was that of "master and servant". It also recommended that the privileged status of the administration be brought to an end. Furthermore, the Commission advocated that the NEC formally denounced the use of violence and torture on members. Other recommendations included the immediate improvement of the diet in the camps. In chapter twenty, Manong recalls the role played by Tambo in assisting him and others to further their studies in Hungary at the Budapest Technical University. The intervention by Tambo in this matter helped him to achieve his childhood aspirations of being an engineer. Chapter twenty-one acknowledges that the ANC leaders made mistakes in the past. What is critical to the author, is the question of accepting the mistakes made and correcting them, without showing signs of arrogance. However, in this chapter, 
the author appears to have placed undue emphasis on acknowledging Tambo's humility in dealing with the challenges that confronted the ANC in exile.

If we must die narrates the history of the ANC in exile about which many South Africans know very little. This is a thoroughly researched book with all relevant sources acknowledged. Despite the above accolades aligned to this publication, the following shortcomings were spotted: inconsistencies in the writing of the word Sechaba or SECHABA; Vusi Mayekso instead of Vusi Mayekiso (p. 145); Luasaka instead of Lusaka (p. 249). The book is a must read for history students and academics. It can be used as a useful reference source for the history of the liberation struggle. 